ISSN 2089-8673

Jurnal Nasional Pendidikan Teknik Informatika (JANAPATI)

Volume 1, Nomor 1, Maret 2012

\title{
Pemanfaatan Teknologi Open Source Dalam Pengembangan Proses Belajar Jarak Jauh di Perguruan Tinggi
}

\author{
Ferrianto Gozali dan Billion Lo \\ Jurusan Teknik Elektro, Fakultas Teknologi Industri, Universitas Trisakti, Jakarta \\ (ferrianto@trisakti.ac.id, billion@std.trisakti.ac.id )
}

\begin{abstract}
ABSTRAK
Perkembangan Teknologi Informasi dan Komunikasi atau disingkat TIK yang ada saat ini ikut memberikan kontribusi dalam pengembangan bidang pendidikan khususnya di perguruan tinggi, termasuk dalam proses belajar mengajar. Proses belajar mengajar yang bersifat konvensional, dimana dosen dan mahasiswa melakukan kegiatan tatap muka di ruang kelas, sudah mulai beralih ke proses belajar jarak jauh dengan memanfaatkan TIK dalam bentuk e-learning. Dengan memanfaatkan proses e-learning ini, masalah waktu dan tempat yang biasa kita temui dapat dipecahkan, terutama pada keterbatasan ukuran kelas terhadap jumlah murid dan keterbatasan waktu untuk dapat hadir di ruang kelas.

E-Learning berkembang sejalan dengan perkembangan TIK, dimana konsep E-Learning 1.0 terus mengalami perbaikan menuju ke E-Learning 2.0. Perkembangan konsep ini terutama dijumpai dalam bentuk komunikasi pada proses yang disediakan, jenis media yang digunakan dan peran dosen (Pengajar) dan mahasiswa (murid) dalam proses belajar mengajar tersebut.

Deklarasi gerakan Indonesia Go Open Source atau IGOS oleh lima menteri pada tanggal 3 juni 2004 serta keharusan bagi seluruh instansi pemerintah untuk menggunakan perangkat lunak legal paling lambat Desember 2011 ikut mendorong perkembangan e-learning dengan menggunakan teknologi open source seperti Sistem Operasi Linux, Learning Management System LMS (moodle, Sakai, Dukeos), Blog (Wordpress, Joomla, Drupal), Netmeeting, Animasi dan Simulasi (Flash dan Blender). Tulisan ini akan membahas tentang pemanfaatan teknologi open source yang tersedia saat ini dalam pengembangan proses belajar jarak jauh khususnya di perguruan tinggi.
\end{abstract}

Kata Kunci: e-learning, open source.

\section{Pendahuluan}

Perkembangan Teknologi Informasi dan Komunikasi atau disingkat TIK yang ada saat ini ikut memberikan kontribusi dalam pengembangan bidang pendidikan khususnya di perguruan tinggi. Salah satu kegiatan yang paling utama adalah proses belajar mengajar. Proses belajar mengajar yang bersifat konvensional, dimana dosen dan mahasiswa melakukan kegiatan tatap muka di ruang kelas seringkali mengalami berbagai kendala khususnya dalam waktu dan tempat. Untuk mengatasi kendala tersebut maka dikembangkan proses belajar jarak jauh dengan memanfaatkan TIK dalam bentuk e-learning. Dengan memanfaatkan proses e-learning ini, masalah waktu dan tempat yang biasa kita temui dapat dipecahkan, terutama pada keterbatasan ukuran kelas terhadap jumlah murid dan keterbatasan waktu untuk dapat hadir di ruang kelas.

Ketersediaan berbagai perangkat lunak yang bersifat open source serta deklarasi gerakan Indonesia Go Open Source (IGOS) merupakan landasan yang kuat dalam pengembangan e-learning dengan menggunakan berbagai applikasi yang bersifat open source. Pada tulisan ini ini, akan dibahas penggunaan tools open source dalam pengembangan proses belajar jarak jauh tersebut. Seperti yang sudah kita ketahui, tools open source tersebut umumnya tidak berbayar dan terbuka bagi setiap 
ISSN 2089-8673

Jurnal Nasional Pendidikan Teknik Informatika (JANAPATI)

Volume 1, Nomor 1, Maret 2012

pengembang aplikasi untuk mengembangkan, memodifikasi atau mengintegrasikan dengan aplikasi lain. Berikut beberapa tools opensource yang umum digunakan sebagai penunjang e-learning : sistem operasi linux, Learning Management System (Moodle, Sakai, Dokeos), Weblog (Wordpress, Drupal, Joomla), dll.

\section{Teknologi Open Source}

Kata open source mungkin bukan merupakan istilah yang asing lagi, open source sering identik dengan Sistem Operasi Linux, namun open source bukan hanya itu. Terdapat banyak perangkat lunak lainnya yang berjalan di Linux, Windows maupun MacOS termasuk dalam kategori open source, seperti Open Office, Mozilla Firefox, LAMP / WAMP / MAMP (akronim dari Linux / Windows / Mac Apache Mysql PHP), dan banyak lagi. Label Open Source pertama kali ditemukan pada tahun 1998 oleh beberapa orang, termasuk Erick Raymond yang menjadi founder dari OSI (Open Source Initiative) yang merupakan organisasi yang mengarahkan dan melakukan standarisasi bagi berbagai perangkat lunak yang open source.

Open source merupakan sebuah metode pengembangan perangkat lunak yang memanfaatkan kekuatan dari pengembang yang tersebar dengan latar belakang yang berbeda-beda dan proses yang transparan. Dengan open source diharapkan dapat dihasilkan perangkat lunak yang berkualitas, andal, fleksibel, murah dan mengakhiri keterikatan terhadap vendor tertentu yang berbayar. Beberapa lisensi yang sering ditemukan pada perangkat lunak open source antara lain: GNU Public License (GPL), Apache License, Mozilla Public License (MPL), dll. Berikut ini beberapa kriteria sebuah perangkat lunak dapat dikatakan perangkat lunak yang open source :

- Didistribusi secara gratis, tidak melarang untuk menjual atau memberikan perangkat lunak tersebut sebagai komponen dari pengembangan perangkat lunak lain.

- Program harus disertakan dengan source code dan diperbolehkan untuk didistribusikan termasuk kode yang telah dikompilasi

- Melarang untuk mendistribusikan source code dalam format yang telah dimodifikasi saja, tanpa source code asli dari pembuatnya.

- Melarang adanya diskriminasi penggunaan program bagi perorangan atau kelompok

- Melarang adanya diskriminasi penggunaan program bagi bidang tertentu (bisnis, research, edukasi, dII)

- Lisensi tidak mengharuskan semua program yang didistribusi pada medium yang sama harus merupakan perangkat lunak yang open source

Kampanye open source yang mulanya digalakkan di Amerika Serikat, mulai diadaptasi oleh berbagai negara didunia, salah satunya Indonesia melalui Deklarasi "Indonesia, Go Open Source! (IGOS)" pada tanggal 30 Juni 2004 yang ditanda tangan oleh 5 Menteri, yaitu Menteri Riset dan Teknologi Hatta Rajasa, Menteri Kommunikasi dan Informasi H. Syamsul Mu'arif, Menteri Pendayagunaan Aparatur Negara H. M. Feisal Tamin, Menteri Kehakiman dan HAM Yusril Ihza Mahendra dan Menteri Pendidikan Nasional Abdul Malik Fadjar dengan issue penggunaan perangkat lunak legal di setiap instansi pemerintah dan pemanfaatan perangkat lunak Open Source di Indonesia.Dari permikiran ini lah timbul gerakan untuk pemanfaatan perangkat lunak Open Source di bidang pendidikan.

\section{Proses Belajar Jarak Jauh}

E-learning adalah segala jenis proses transfer skill dan pengetahuan melalui media komputer, jaringan komputer atau internet. Jenis aplikasi e-learning dapat dalam bentuk aplikasi berbasis web, aplikasi berbasis komputer, pendidikan virtual dan segala konten digital yang mengukung proses pengajaran seperti audio, gambar, video, dan animasi. 
ISSN 2089-8673

Jurnal Nasional Pendidikan Teknik Informatika (JANAPATI)

Volume 1, Nomor 1, Maret 2012

\section{III.1. Proses Belajar Konvensional vs E-Learning}

Proses belajar mengajar yang konvensional mempunyai karakteristik, dimana proses terjadi tatap muka secara langsung antara pengajar dan murid. Proses belajar dengan menggunakan applikasi elearning mempunyai karakteristik, dimana proses belajar mengajar bisa terjadi dimana saja dan kapan saja dengan dan tanpa interaksi secara langsung dengan pengajar. Kelebihan dari metode e-learning jika dibandingkan dengan metode konvensional antara lain:

- Proses belajar mengajar tidak terikat pada waktu dan tempat

- Materi yang diterima oleh murid seragam

- Efisiensi biaya, dimana jumlah pengajar dapat diminimalisir dan biaya transportasi maupun akomodasi yang dibutuhkan pengajar pada metode pengajaran konvensional dapat dieliminasi.

- Support just in time training, dimana pelajar / pegawai perusahaan tidak perlu menghapal materi yang diberikan, namun materi tersebut dapat dicari dan dipelajari kapan saja dibutuhkan

Namun demikian, terdapat beberapa faktor yang menghambat pengadopsian e-learning sebagai pengganti belajar mengajar yang konvensional antara lain:

- Hambatan Organisasi, masalah yang dihadapi seperti:kurangnya kesiapan dalam kultur pendidikan organisasi, ketidak mampuan untuk memasarkan program, kurangnya keselarasan program dengan misi dan visi organisasi, rendahnya dukungan dari menejemen organisasi,dan kegagalan untuk menetapkan ekspektasi dari program

- Ketidakcocokan metode belajar mengajar, masalah yang dihadapi seperti: kegagalan untuk focus pada murid dan ketidak cocokan penggunaan e-learning sebagai metode belajar mengajar yang mandiri

- Masalah Teknologi, meliputi isu seperti: membutuhkan SDM pengajar yang mengerti IT dalam proses belajar mengajar, perencanaan dalam pengintegrasian dengan sistem yang telah ada, dan pengembangan hanya terfokus pada Teknologi saja, namun tidak pada metode pengajaran

- Masalah Dana, masalah yang dihadapi terutama pada saat pengembangan, dimana membutuhkan dana yang besar. Pada umumnya pengambil keputusan hanya menghitung biaya yang dikeluarkan, namun mengabaikan efisiensi yang dihasilkan dari implementasi metode elearning.

\section{III.2. Perkembangan E-Learning}

Seiring dengan perkembangan zaman dan perkembangan teknologi, konsep dari e-learning juga mengalami evolusi.Dimulai pada awal 1960, Prof. Patrick Suppes dan Richard C. Atkinson dari Stanford University mengembangkan Program edukasi dengan menggunakan bagi sekolah dasar. Dengan adanya internet dan ditemukannya web, email, dll, pada tahun 1993 William D Graziadei menjelaskan penggunaan email sebagai media pembelajaran online, berkembang hingga pada tahun 1997, beliau mengeluarkan publikasi yang menjelaskan strategi pengembangan materi dan menejemen untuk sistem edukasi yang berbasis teknologi. E-learning berkembang hingga saat ini, dimana terdapat banyak teknologi yang mendukung untuk proses pembelajaran, seperti blogs, e-Portofolio hingga virtual classroom.

Saat ini perkembangan E-Learning menuju kearah E-Learning 2.0 Istilah e-Learning 2.0 digunakan untuk merujuk kepada cara pandang baru terhadap pembelajaran elektronik yang terinspirasi oleh munculnya teknologi Web 2.0.Web 2.0, adalah sebuah istilah yang dicetuskan pertama kali oleh O'Reilly Media pada tahun 2003, dan dipopulerkan pada konferensi web 2.0 pertama di tahun 2004.

Sebelum menuju ke E-Learning 2.0, telah digunakan konsep E-Learning 1.0 (primitive) yang merupakan Sistem konvensional pembelajaran elektronik biasanya berbasis pada paket pelajaran yang disampaikan kepada siswa dengan menggunakan teknologi Internet.Peran siswa dalam pembelajaran terdiri dari pembacaan dan mempersiapkan tugas. Kemudian tugas dievaluasi oleh guru.Sebaliknya, elearning 2.0 memiliki penekanan pada pembelajaran yang bersifat sosial dan penggunaan perangkat 
ISSN 2089-8673

Jurnal Nasional Pendidikan Teknik Informatika (JANAPATI)

Volume 1, Nomor 1, Maret 2012

lunak sosial (social networking), tabel.1. berikut yang memperlihatkan perbedaan antara E-Learning 1.0 (primitive) dan E-Learning 2.0.

Tabel 1, Perbedaan E-Learning 1.0 dan E-Learning 2.0

\begin{tabular}{|l|l|l|}
\hline Arah Komunikasi & \multicolumn{1}{|c|}{ E-Learning 1.0 } & \multicolumn{1}{c|}{ E-Learning 2.0 } \\
\hline $\begin{array}{l}\text { Distribusi Proses } \\
\text { Pembelajaran }\end{array}$ & Berasal Pengajar & $\begin{array}{l}\text { Terdistribusi secara rata untuk semua } \\
\text { partisipan, baik pengajar maupun murid }\end{array}$ \\
\hline Materi & $\begin{array}{l}\text { Dalam bentuk PowerPoint, } \\
\text { Document tulisan maupun gambar }\end{array}$ & $\begin{array}{l}\text { Dalam bentuk Web Confrence, Simulasi } \\
\text { dalam bentuk Animasi, Video dan Audio }\end{array}$ \\
\hline Media & $\begin{array}{l}\text { LMS yang berisi repository materi } \\
\text { kuliah dan tugas }\end{array}$ & $\begin{array}{l}\text { LMS yang diintegrasikan dengan fitur social } \\
\text { networking, seperti blog, wiki, podcast, Audio } \\
\text { dan Video, Web Conference, hingga Animasi } \\
\text { atau simulasi }\end{array}$ \\
\hline Peran E-learning & $\begin{array}{l}\text { Suplemen dari proses kegiatan } \\
\text { belajar mengajar konvensional di } \\
\text { kelas }\end{array}$ & $\begin{array}{l}\text { Substitusi dari proses belajar mengajar di } \\
\text { kelas }\end{array}$ \\
\hline $\begin{array}{l}\text { Definisi Penilaian } \\
\text { dan Pencapaian }\end{array}$ & $\begin{array}{l}\text { Dari pengajar, sesuai dengan } \\
\text { standard dari Institusi Pendidikan }\end{array}$ & Dari murid, dengan bantuan dari pengajar \\
\hline Penilaian & \begin{tabular}{l} 
Dari Pengajar \\
\hline
\end{tabular}
\end{tabular}

\section{III.3. E-Learning dan Open Source}

Perkembangan E-Learning tidak terlepas dari banyaknya perangkat lunak yang bersifat open source yang tersedia dan dapat digunakan maupun dimodifikasi sesuai dengan kebutuhan proses belajar mengajar.Perkembangan E-Learning yang berbasis web dan internet dimulai dengan adanya LMS yang dimulai pada awal tahun 1990an, dimana banyak LMS yang berbayar dibuat dan dikembangkan, salah satunya WebCT yang dipublikasikan pada 1998, yang hingga saat ini masih digunakan sebagai salah satu LMS yang berbayar, dan pada 2001 moodle yang merupakan LMS open source dipublikasikan dan E-Learning terus berkembang hingga saat ini. Pada tahun 2000an juga banyak perangkat lunakperangkat lunak yang dibuat yang membantu proses evolusi dari E-Learning, dimana adanya blog yang open source (Wordpress, Joomla, Drupal), Media sharing seperti Youtube yang opensource ( PhpMotion dan OsTube), dll.

\section{III.4. Tools E-Learning yang Open Source}

Dalam mendukung perkembangan E-Learning diperlukan tools, berikut ini beberapa tools opensource yang dapat digunakan :

\section{III.4.1.Sistem Operasi Linux}


ISSN 2089-8673

Jurnal Nasional Pendidikan Teknik Informatika (JANAPATI)

Volume 1, Nomor 1, Maret 2012

Secara umum, Linux adalah suatu sistem operasi yang serupa namun tidak sama dengan sistem operasi Unix,dimana Linux bebas biaya lisensi dan dapat diperoleh oleh siapapun, dengan lisensi dibawah GNU Public License (GPL).

Sistem operasi Linux mengacu pada kernel yang dibuat oleh Linus Torvald dan didistribusikan dengan nama yang sama diberbagai situs didunia. Kernel merupakan bagian inti dari sistem operasi, dan berbagai distribusi Linux seperti Red Hat, SuSE, Debian, Slackware dan distribusi linux lainnya mengembangkan driver dari perangkat keras, integrasinya dengan aplikasi-aplikasi diatasnya dan GUI (Graphical User Interface) yang dibutuhkan.

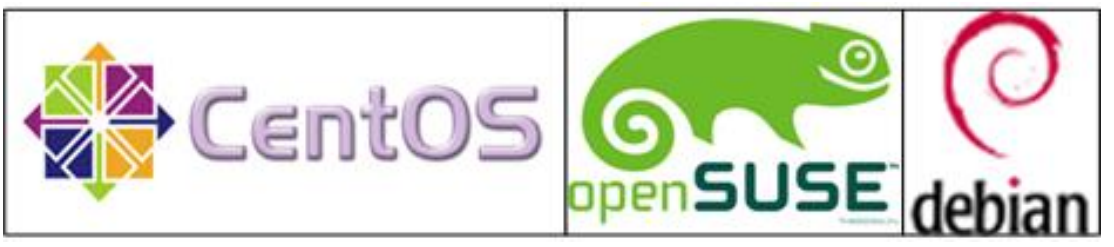

Gambar 1. Contoh Beberapa Distribusi Linux

Sistem operasi Linux dapat digunakan pada perangkat computer yang low end hingga server dengan berbagai distribusi linux yang dapat dipilih sesuai dengan kebutuhan pemakaian.Tidak hanya digunakan diperangkat computer, Sistem operasi linux ini juga digunakan diperangkat smartphone.Salah satunya adalah Android yang merupakan sistem operasi yang dikembangkan oleh Google yang sedang naik daun, dimana lebih dari 1/3 perangkat smartphone didunia menggunakan sistem operasi tersebut.

\section{III.4.2.Learning Management System (LMS)}

LMS merupakan suatu sistem yang dikembangkan untuk mendukung lingkungan belajar dan mengajar berbasis web.Terdapat beberapa vendor yang menyedikan LMS yang bersifat open source yang popular digunakan adalah Moodle, Sakai dan Dokeos.

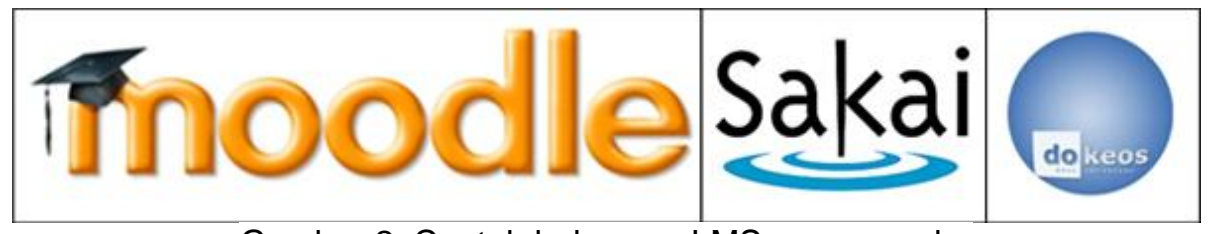

Gambar 2. Contoh beberapa LMS yang populer

LMS menyediakan kemampuan bagi para pengajar untuk membangun website yang dinamis untuk mendukung lingkungan belajar yang baik bagi muridnya.LMS umumnya menyediakan fitur:

- Menejemen dari perkuliahan, seperti hak akses user ke suatu mata kuliah, dapat sebagai pengajar, murid atau coordinator mata kuliah; tenggang waktu perkuliahan, materi perminggu, dll.

- Menyediakan pelaporan aktivitas dan nilai dari murid.

- Media komunikasi antara pengajar dengan murid, dalam bentuk forum, chat, blog dan wiki.

- Menyediakan sarana pengumpulan tugas, quiz dan ujian.

- Menyediakan data repository materi mata kulaih yang sedang diambil.

Dilihat dari fitur-fitur yang disediakan oleh LMS; dapat dilihat bahwa LMS memegang peran penting dalam perkembangan e-learning yaitu untuk menyediakan sarana administrasi dan pelaporan permatakuliahan atau kursus bagi pengajar maupun murid. 
ISSN 2089-8673

Jurnal Nasional Pendidikan Teknik Informatika (JANAPATI)

Volume 1, Nomor 1, Maret 2012
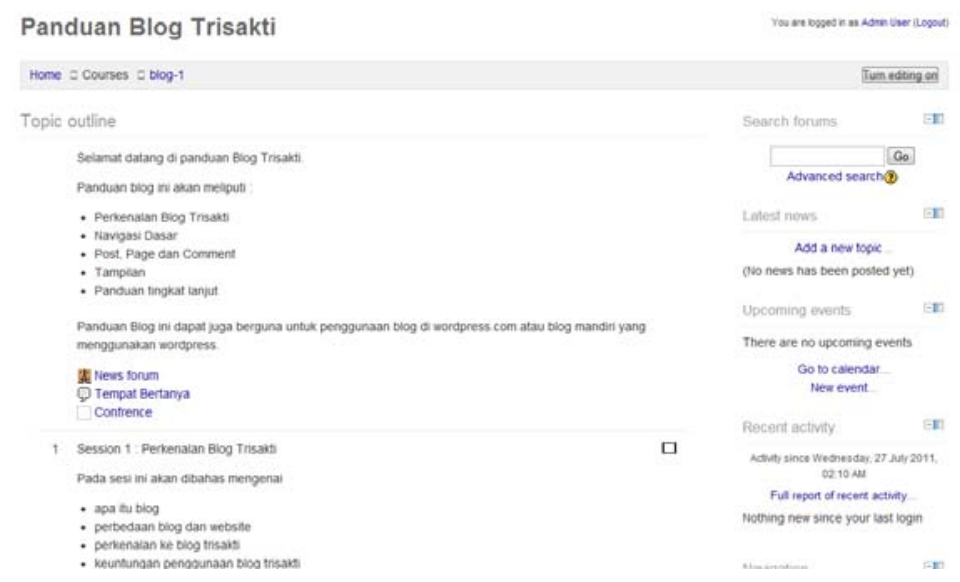

Gambar 3. Contoh hasil implementasi Moodle

\section{III.4.3.Blog}

Blog merupakan singkatan dari "web log" yang merupakan sebuah media komunikasi dari pribadi atau komunitas yang berbasis internet.Informasi yang disediakan dapat berupa edukasi, panduan travel, pengalaman pribadi, kesehatan dll.Sesuai dengan fungsinya, dalam E-Learning blog merupakan fasilitas dimana pengajar dapat sharing pengetahuan, informasi perkuliahan dan tanya jawab.

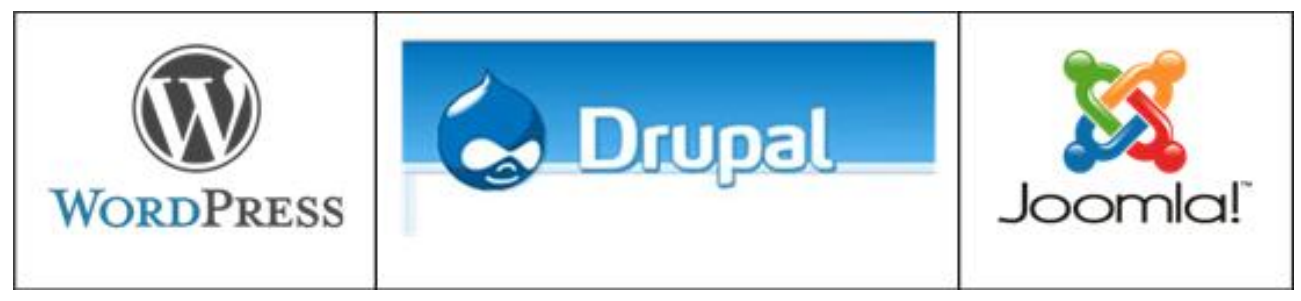

Gambar 4. Beberapa contoh CMS blog open source

Terdapat beberapa perangkat lunak CMS (Content Management System) berbasis open source yang popular digunakan untuk membantu dalam pembuatan blog, yaitu Wordpress, Joomla dan Drupal.

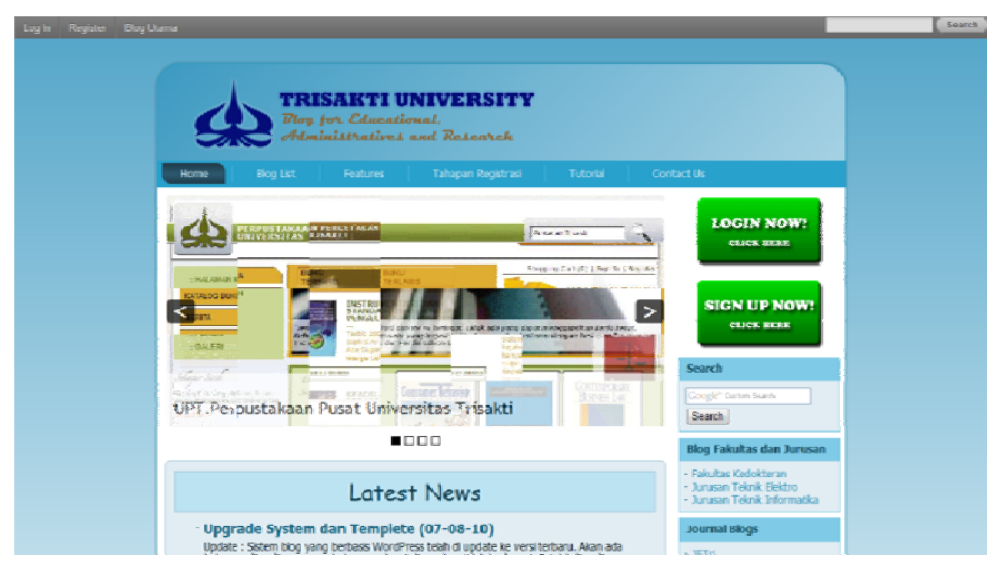


ISSN 2089-8673

Jurnal Nasional Pendidikan Teknik Informatika (JANAPATI)

Volume 1, Nomor 1, Maret 2012

Gambar 5. Penggunaan blog dalam bidang Pendidikan

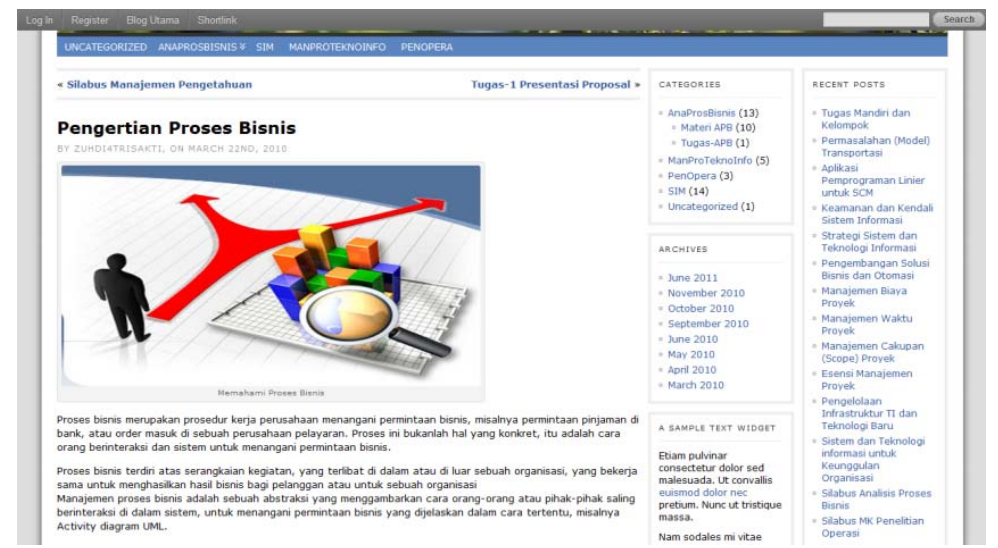

Gambar 6. Contoh posting blog dalam dunia Bisnis

\section{III.4.4.Netmeeting}

Netmeeting merupakan perangkat lunak yang menyediakan layanan untuk melakukan Conference (tiap pengguna conference dapat bertatap muka dan berbicara satu sama lain didalamnya, komunikasi yang dilakukan dua arah) dan Seminar (pengguna seminar hanya dapat melihat dan mendengar si pemateri, komunikasi yang dilakukan hanya satu arah) melalui Web. Terdapat perangkat lunak yang berbayar seperti produk Windows dan open source seperti Dim Dim, untuk melakukan Netmeeting.

Fitur-Fitur yang tersedia dalam Netmeeting umumnya adalah :

- Komunikasi dalam bentuk Video dan atau Audio.

- Ada Papan Tulis, yang dapat menggambar, menulis dan mengedit baik gambar maupun dokumen. Hasil gambar atau dokumen yang ditampilkan di Papan tulisa dapat di simpan dan dipanggil kembali.

- Terdapat fitur BackUp datadan merekam proses perkuliahan.

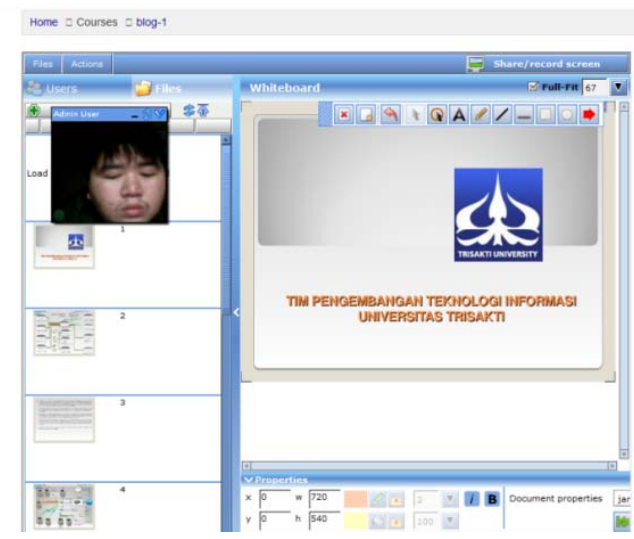

Gambar 7. Tampilan penggunaan Netmeeting dalam Edukasi

\section{III.4.5.Flash Animation dan Blender}


ISSN 2089-8673

Jurnal Nasional Pendidikan Teknik Informatika (JANAPATI)

Volume 1, Nomor 1, Maret 2012

Animasi atau simulasi dalam sangatlah membantu dalam proses belajar mengajar, terutama dalam belajar mengajar peningkatan skill, dimana murid dapat belajar dan bereksperimen mendekati kondisi nyata. Animasi ini dapat dikembangkan dengan menggunakan perangkat lunak seperti Adobe Flash yang merupakan perangkat lunak yang berbayar dan juga Blender yang merupakan perangkat lunak open source yang dapat membantu pengembangan animasi 3D, dimana animasi dalam bentuk 3D ini akan sangat berguna dimasa yang akan datang.

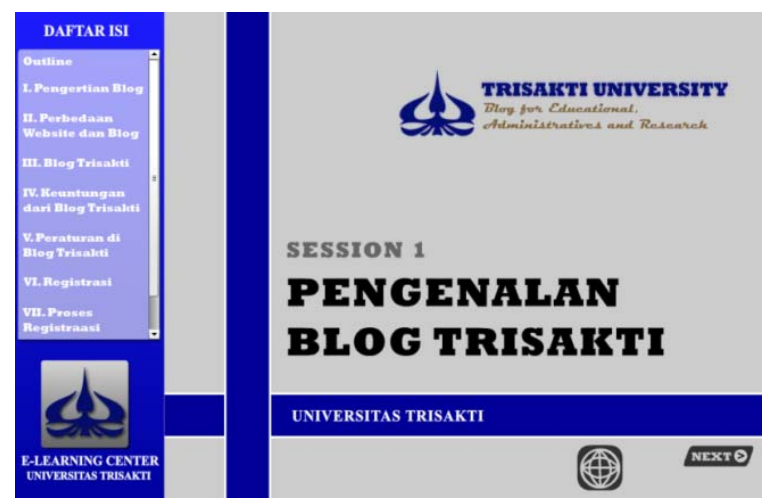

Gambar 8. Gambar aplikasi flash untuk mendukung pengenalan blog di Univ Trisakti

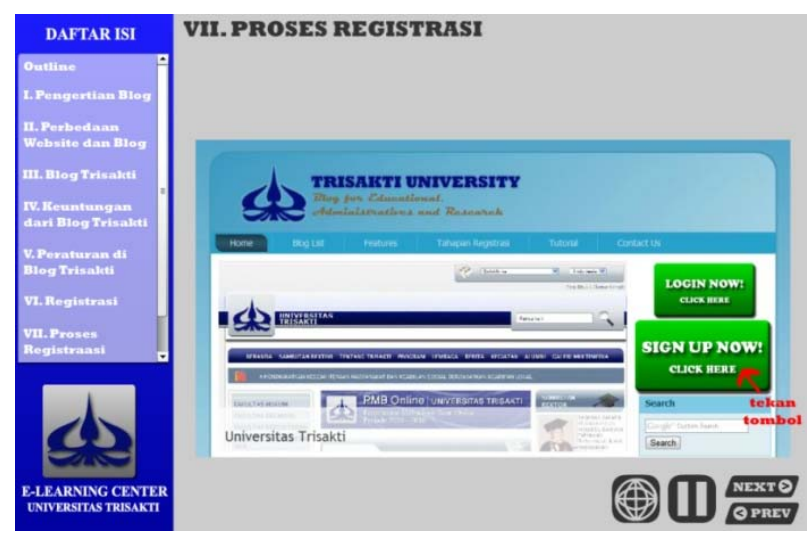

Gambar 9 Gambar aplikasi flash untuk mendukung pengenalan blog di Univ Trisakti

\section{III.5.Arsitektur E-Learning}




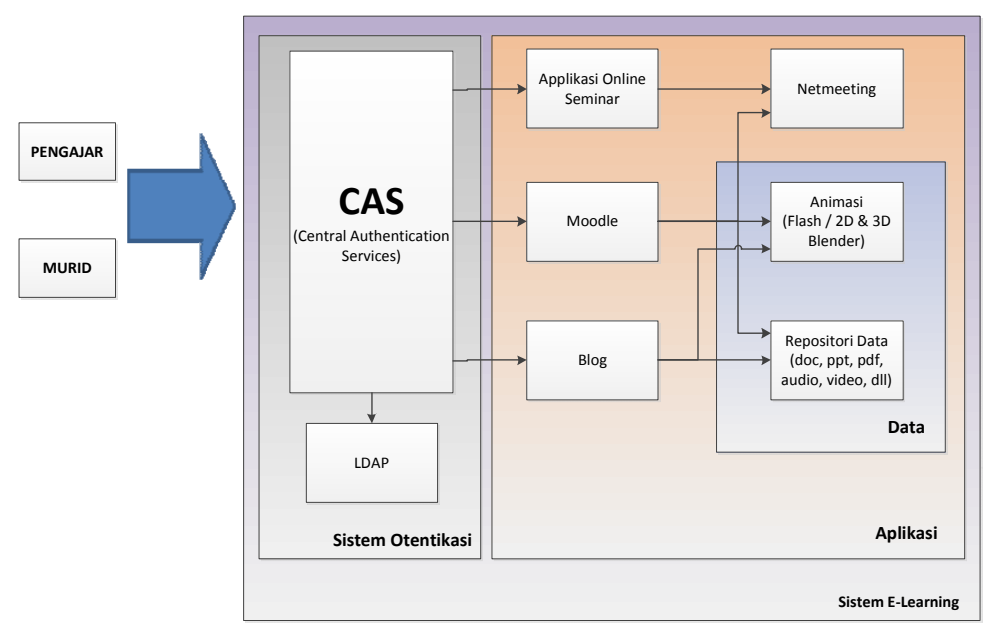

Gambar 10. Sistem Arsitektur E-Learning

Pada gambar 10 diatas, digambarkan Arsitektur dari implementasi Sistem E-Learning. Dalam Sistem E-Learning ini, terbagi menjadi 3 sub bagian yang penting, yaitu :Sistem Otentikasi, Aplikasi dan Data.

Pada sistem terdapat aplikasi Online Seminar, Moodle, dan Blog. Aplikasi Online seminar merupakan aplikasi yang menyediakan layanan seminar bagi para murid berbasis internet, yang memungkinkan seminar yang pengajar berasal dari luar kota atau luar negri. Pada aplikasi ini, diatur mekanisme pendaftaran seminar dan pembukaan ruangan seminar.

Aplikasi Online Seminar dan Moodle mengakses aplikasi Netmeeting yang menjadi backend (core engine kegiatanWeb Conference). Untuk mendukung proses belajar, moodle dan blog mengakses Data Animasi dan Repositori data sebagai bahan materi.

Sebagai pengguna sistem E-Learning ini, pengajar maupun murid perlu melakukan otentikasi terlebih dahulu melalui CAS untuk dapat mengakses Aplikasi Online Seminar dan Moodle. Namun untuk mengakses materi atau posting dari Blog, tidak perlu melakukan otentikasi, tetapi jika user ingin memposting tulisan, user tetap perlu melakukan otentikasi.

Pada Proses Otentikasi diatur mekanisme pendaftaran pengguna, baik pengajar dan mahasiswa serta hak akses ke aplikasi yang tersedia. Pada sistem Otentikasi ini digunakan CAS (Central Authentication Services) dan LDAP. Use case diagram untuk proses registrasi dapat dilihat pada Gambar 11 berikut:

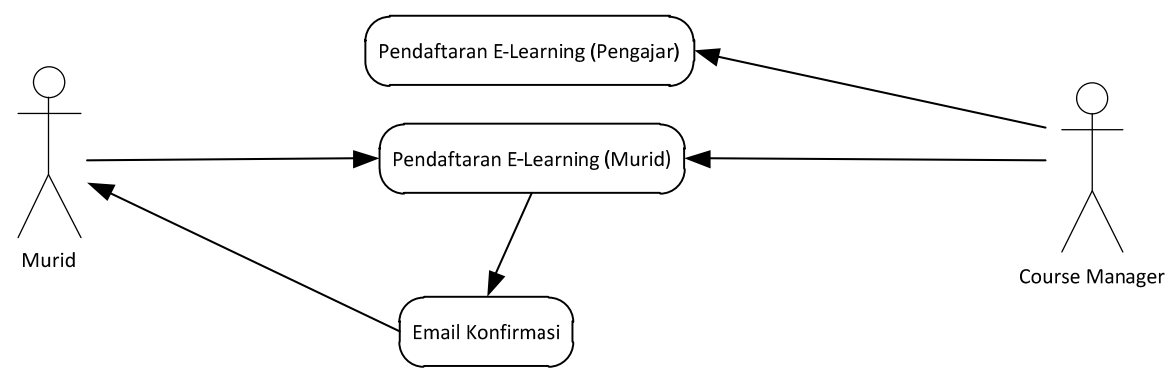

Gambar 11. Use Case Diagram untuk proses Registrasi 
ISSN 2089-8673

Jurnal Nasional Pendidikan Teknik Informatika (JANAPATI)

Volume 1, Nomor 1, Maret 2012

Pada gambar 11 diatas terlihat, proses Pendaftaran E-Learning yang dilakukan oleh mahasiswa (murid) dan dipantau oleh Course Manager. Email konfirmasi status pendaftaran akan diterima oleh murid tersebut sedangkan proses pendaftaran dosen Pengajar (dosen) dilakukan oleh Course Manager.

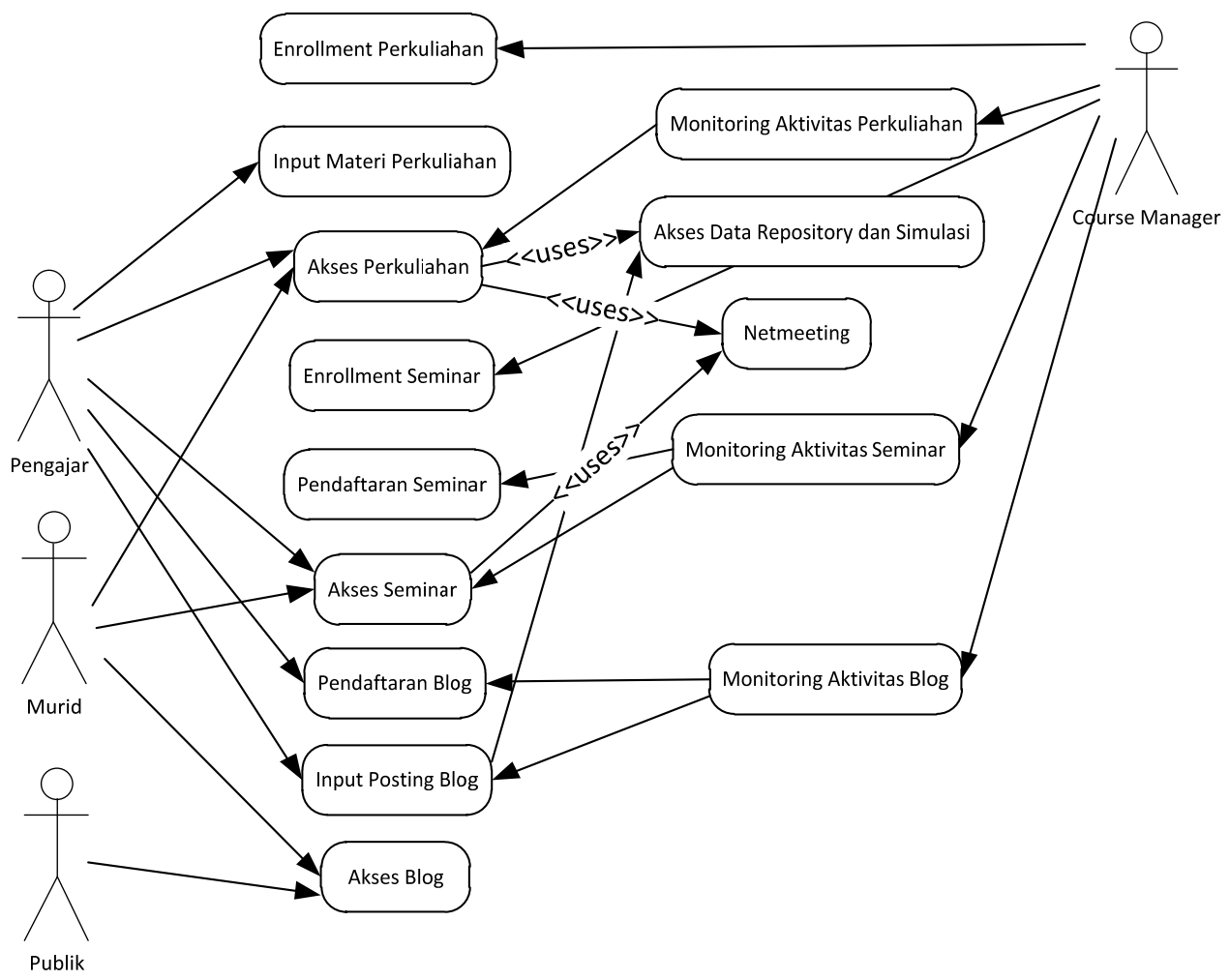

Gambar 12. Use Case Diagram secara umum sistem E-Learning

Pada gambar 12, terlihat terdapat 4 aktor yang terdiri dari Course Manager, dosen atau pengajar, murid (mahasiswa) dan publik (umum) .Pada bagian perkuliahan, yang diatur oleh Moodle, Course Manager berperan sebagai pengatur kelas, baik pengajar yang mengajar kuliah tersebut, dan murid yang akan mengikuti kuliah.

Pengajar berperan sebagai penginput materi perkuliahan. Perkuliahan tersebut nantinya akan diakses oleh pengajar dan murid terutama pada saat menggunakan aplikasi netmeeting, perkuliahan tersebut juga dapat menggunakan animasi yang telah dibuat dan data repository yang disimpan ditempat yang terpisah.

Online Seminar menggunakan aplikasi netmeeting sebagai backend nya.Dalam hal ini, Course Manager berperan sebagai pengatur seminar dan akses pengajar luar. Pengajar dan murid dapat mengakses Online seminar tersebut.

Pada blog, pendaftaranhanyadilakukanolehpengajar, denganpemantauan Course Manager.Padasaatmelakukan posting blog, pengajardapatmenggunakananimasidan data repository untukmenyusun posting tersebutdan posting tersebutdapatdilihatolehmuriddanmasyarakat public secara bebas. 
ISSN 2089-8673

Jurnal Nasional Pendidikan Teknik Informatika (JANAPATI)

Volume 1, Nomor 1, Maret 2012

\section{Arah Perkembangan E-Learning di masa yang akan datang}

Berikut beberapa trend perkembangan E-Learning dimasa yang akan datang :

- Proses belajar mengajar yang sebelumnya sudah berbasis pada komputer dan internet akan bergeser ke dunia mobile, dimana perkembangan Smartphone sangat cepat terutama berasal dari Sistem Operasi IOS (Apple) dan Android (Google).

- Media pembelajaran dalam bentuk animasi dan simulasi akan sangat dominan dalam proses belajar mengajar, terutama untuk peningkatan skill.

- Pembelajaran akan terpusat pada murid, dimana akan terdapat suatu mekanisme yang dapat mengadaptasikan kebiasaan murid dalam proses pembelajaran secara personal dari murid tersebut.

\section{Kesimpulan}

Penggunaan E-Learning sudah bukan merupakan hal yang sulit lagi. Sudah terdapat banyak perangkat-perangkat lunak yang dapat digunakan tertutama yang berbasis open source, yang dapat mengurangi biaya yang dibutuhkan dalam pengembangan sistem. Terdapat beberapa perangkat lunak open source yang dapat digunakan, seperti Sistem Operasi Linux, LMS (moodle, Sakai, Dukeos), Blog (Wordpress, Joomla, Drupal), Netmeeting, Animasi dan Simulasi (Flash dan Blender).

Dengan adanya E-Learning ini diharapkan dapat menjadi substitusi bagi kegiatan belajar mengajar yang konvensional didalam kelas dimana terdapat berbagai macam keterbatasan yang dapat ditemui.

\section{Daftar Pustaka}

1. Rosen, Anita. 2009, E-Learning 2.0 : proven practices and emerging technologies to achieve results, New York: AMACOM

2. Chao, Lee. 2009, Utilizing open source tools for online teaching and learning : applying Linux technologies, Hershey PA: Information Science Reference

3. Carliner, Saul; Shank, Patti.2008, The E-Learning Handbook, San Francisco: John Willey and Sons

4. Kozlowski ,Timo. E-Learning 1.0 and E-learning 2.0, Paper for the International E-Learning Conference at the Rajabhat Suan Dusit University.

5. Lo, Billion. 2009, Implementasi Sistem Dynamic Virtual Local Area Network untuk Aplikasi Web Confrence, Jakarta: Universitas Trisakti

6. Ramadhana, Yovira. 2008, Sistem Konferensi Video Berbasis Web dengan Menggunakan Aplikasi Open Source, Freeware dan Shareware, Jakarta: Universitas Trisakti 